\title{
Toxicological estimation of mortality of oceanic sea turtles oiled during the Deepwater Horizon oil spill
}

\author{
C. L. Mitchelmore ${ }^{1, *}$, C. A. Bishop ${ }^{2}$, T. K. Collier ${ }^{3}$ \\ ${ }^{1}$ Chesapeake Biological Laboratory, University of Maryland Center for Environmental Science, 146 Williams Street, \\ Solomons, MD 20688, USA \\ ${ }^{2} 657$ 202nd Street, Langley, British Columbia V2Z 1V7, Canada \\ ${ }^{3}$ Joint Office for Science Support, University Corporation for Atmospheric Research, 3300 Mitchell Lane, Boulder, CO 80301, USA
}

\begin{abstract}
Using multiple lines of evidence, we estimated the mortality of oceanic sea turtles that were minimally to moderately oiled by the 2010 BP Deepwater Horizon (DWH) oil spill in the Gulf of Mexico. Using estimates of the oil ingested by oceanic sea turtles and comparing them to toxic endpoints following oil ingestion in turtles and other vertebrate species, we derived an estimated percentage of mortality for oil-exposed oceanic sea turtles. Oil ingestion $\left(\mathrm{mg} \mathrm{kg}^{-1} \mathrm{BW} \mathrm{d}^{-1}\right)$ in oceanic sea turtles was estimated based on extent of oiling categories assigned by a sea turtle technical working group (STTWG) as follows: non-oiled (0), minimally oiled (1), lightly oiled (2), moderately oiled (3) and heavily oiled (4). Because the STTWG concluded that $100 \%$ of heavily oiled turtles would have died from the physical effects of heavy oiling, we limited our assessment of mortality to turtles in categories 0 to 3 and estimated how many of these turtles would have died from ingestion of oil. The estimated mortality was $85 \%$ for category 3,50\% for category 2 and $25 \%$ for category 1 . Visibly non-oiled turtles (category 0 ) were assigned $0 \%$ mortality. To calculate the overall mortality for all turtles, the mortality estimations for categories 0 to 3 were applied to the numbers of turtles observed with different degrees of oiling, as documented by direct capture operations during the DWH spill. We concluded that, overall, approximately $30 \%$ of all oceanic turtles in the region affected by the DWH spill that were not heavily oiled would have died from ingestion of oil.
\end{abstract}

KEY WORDS: Toxicology · Mortality · Oceanic sea turtles $\cdot$ Deepwater Horizon · Oil spill $\cdot$ NRDA

\section{INTRODUCTION}

The explosion and sinking of the Deepwater Horizon (DWH) drilling platform in April 2010 caused one of the world's largest marine oil spills, releasing millions of barrels of MC252 crude oil into the Gulf of Mexico (GoM) before the well was capped in July 2010 (McNutt et al. 2012). Various species of sea turtles occur in the GoM, and all are listed as endangered under the US Endangered Species Act of 1973

*Corresponding author: mitchelmore@umces.edu
(Goodman Hall \& Belskis 2012). During the response to the DWH oil spill, oceanic juvenile sea turtles were rescued offshore and sent to rehabilitation facilities for treatment and observation (Stacy 2012). However, the entire GoM was not surveyed, and the search effort for exposed turtles was limited to a period starting a few weeks after the spill (from May 17) to September 21, before the wellhead was capped (Stacy 2012). Therefore, the number of sea turtles dying in the wild during the spill or afterward is un-

(C) The authors 2017. Open Access under Creative Commons by Attribution Licence. Use, distribution and reproduction are unrestricted. Authors and original publication must be credited. 
known. Furthermore, there is limited knowledge on the sensitivity of turtles to oil (Vargo et al. 1986a,b,c, Bossart et al. 1995, Lutcavage et al. 1995) or the effects of oil spills on reptiles (Hall et al. 1983, Mignucci-Giannoni 1999, Wikelski et al. 2001, Saba \& Spotila 2003, Camacho et al. 2013).

To investigate the impact of an oil spill, determining the exposure scenario including the magnitude and the duration of potential exposure is essential. Therefore, critical to our assessment was the data obtained from the sea turtles that were rescued offshore during the DWH incident. Rescued sea turtles were scored based on their extent of external oiling with 5 categories assigned as determined visually by photographs and observations in the field (Stacy 2012, DWH Trustees 2015). These categories represented non-oiled (category 0), minimally oiled (category 1), lightly oiled (category 2), moderately oiled (category 3) and heavily oiled (category 4) sea turtles. The volume of oil in their oral cavity was also visually estimated and was proportional to their external oiling level (Mitchelmore 2012a,b, Stacy 2012, DWH Trustees 2015, Mitchelmore et al. 2015a). These oral oil volume estimations were critical to the first step in our assessment to determine potential internal oil exposure levels. Levels of polycyclic aromatic hydrocarbon (PAH) metabolites in the bile and PAHs in tissues were measured in several field-collected oiled turtles and were positively correlated with the degree of external and internal oiling, demonstrating exposure, uptake and absorption of oil (Ylitalo et al. 2015, 2017 [this Theme Section]).

The objective of this work was to first estimate the potential exposure of oceanic sea turtles to oil and then to use this exposure data to estimate the mortality of oceanic sea turtles due to the DWH oil spill. The exposure of oceanic sea turtles to oil could only be estimated based on the limited information collected during the response phase of the spill, when rescue and rehabilitation of sea turtles was a priority, together with models of the potential exposure that occurred in wild sea turtles during the spill event (Stacy 2012, Stacy \& Innis 2015, Stacy et al. 2017 [this Theme Section], Wallace et al. 2017 [this Theme Section], Ylitalo et al. 2017). These 2 sources of information, which provided some estimation of oil exposure, were then used, together with the literature on the toxicity of oil to reptiles and other vertebrates, to estimate mortality. This approach to estimating mortality was novel, and we are not aware of any other mortality estimate assessments in sea turtles that have employed a similar approach.

\section{METHODS}

Mortality was estimated only for oceanic sea turtles, which are defined as post-hatchling small juveniles that are essentially surface obligates and are associated with Sargassum and other floating materials in offshore locations (DWH Trustees 2015). For this assessment, it was assumed that all oceanic sea turtles, regardless of species, were equally sensitive to oil exposure during the spill event. It was concluded by a sea turtle technical working group (STTWG) that $100 \%$ of heavily oiled sea turtles (i.e. category 4) during the DWH spill would have died but for their capture and rehabilitation, primarily due to the physical effects of being mired in heavy oil in high temperatures (Stacy 2012, DWH Trustees 2015, Wallace et al. 2017). Therefore, the mortality estimates we provide pertain only to oceanic sea turtles that were less than heavily oiled, those in the nonoiled (category 0) through moderately oiled (category 3) categories as assigned by Stacy (2012).

We utilized various sources of information to estimate exposure for oceanic sea turtles. This included data provided by the response team and veterinary assessments of captured and rehabilitated turtles during the DWH spill (Stacy 2012, Stacy \& Innis 2015, DWH Trustees 2015, Mitchelmore et al. 2015a, Stacy et al. 2017), particularly the extent of external and internal oiling and, in a small subset of animals, the biliary concentrations of PAH metabolites in sea turtles oiled during the DWH spill (Ylitalo et al. 2015, 2017).

\section{Estimation of daily and $14 \mathrm{~d}$ exposures to oil in DWH-exposed oceanic sea turtles}

To estimate the potential exposure of turtles to DWH oil, we used multiple lines of evidence for estimating internal exposure and uptake of oil in sea turtles following the DWH oil spill. These included the degree of external oiling, an estimation of the extent of oil in the oral cavity and the percentage of oceanic turtles in different oiling categories (see Table 1 and Stacy 2012, DWH Trustees 2015). Detailed descriptions of the criteria used to assign turtles to the different external oiling categories can be found in Stacy (2012), Mitchelmore et al. (2015a) and DWH Trustees (2015). The percentage of turtles with oil in their oral cavity, together with the estimated volume of oil in their oral cavity, is proportional to the extent of external oiling (Table 1). Although our mortality estimations are limited to turtles in categories 0 to 3 , cate- 
Table 1. Relationship between the extent of external oiling categories, the percentage of turtles with oil in their oral cavity, the estimated oral volume of oil and the bile fluorescent aromatic compounds present as PHN equivalents. Ranges show minimum and maximum values with means and number of turtles (where applicable) in parentheses. ND: not determined. Data from Stacy (2012) and Ylitalo et al. $(2015,2017)$, and Mitchelmore et al. (2015)

\begin{tabular}{|c|c|c|c|}
\hline $\begin{array}{l}\text { Extent of visual } \\
\text { external oiling } \\
\text { (category) }\end{array}$ & $\begin{array}{c}\text { Turtles with oil } \\
\text { in oral cavity } \\
(\%)\end{array}$ & $\begin{array}{c}\text { Estimated } \\
\text { volume of oil in } \\
\text { oral cavity (ml) }\end{array}$ & $\begin{array}{l}\text { PHN equivalents } \\
\text { (ng g }{ }^{-1} \text { bile, } \\
\text { wet weight) }\end{array}$ \\
\hline 0: non-oiled & ND & ND & $\begin{array}{c}5400-30000 \\
(15585 ; \mathrm{n}=20)\end{array}$ \\
\hline 1: minimally oiled & 49.2 & $0.05-0.15(0.1)$ & ND \\
\hline 2: lightly oiled & 76.3 & $0.25-0.50(0.38)$ & $(11000 ; \mathrm{n}=1)$ \\
\hline 3: moderately oiled & 93.2 & $1.0-3.0(2.0)$ & ND \\
\hline 4: heavily oiled & 96.6 & $4.0-8.0(6.0)$ & $\begin{array}{c}110000-510000 \\
(370000 ; \mathrm{n}=4)\end{array}$ \\
\hline
\end{tabular}

gory 4 turtles are included in Table 1 to better illustrate the relationship between degree of external oiling and estimated amount of ingested oil.

In addition to oil in their oral cavities, there was evidence of internal exposure to oil by the presence of oil sheens produced from the feces in some of the turtles brought to rehabilitation facilities as well as observations of oil in the gastrointestinal tract during necropsies of some dead oceanic turtles, which provided evidence that sea turtles in the spill zone were ingesting and absorbing oil (Stacy 2012, DWH Trustees 2015). Several dead turtles were necropsied, and bile and tissue samples indicated the presence of PAH metabolites in bile and PAHs in tissues (Ylitalo et al. 2015). Although there were only a few data points, levels of biliary fluorescent aromatic compounds (FACs) were positively associated with the degree of external and internal oiling (Table 1).

The first step in this assessment was to calculate potential exposure doses of oil for each of the oiling categories (i.e. in categories 1-4) based on the 3 estimates of oil in the oral cavity as provided by Stacy (2012) (i.e. minimum, mean and maximum estimated volumes of oil; see Table 1 and Mitchelmore et al. 2015a). To calculate the potential oral oil doses on a per kilogram weight of turtle, 3 separate estimations were made using the minimum, mean and maximum turtle body weights (BWs) from all turtles collected during the recovery effort $(\mathrm{n}=574)$ as provided by B. A. Stacy (pers. comm.). As oiled turtles were weighed following rescue these BWs were calculated from the data sheets contained in the Stacy (2012) report for the purpose of the calculations using data from all of the turtles collected during the recovery effort, except for one very large turtle that was deemed to be an outlier and therefore removed.
The model results are presented in Tables S1 to S3 (in the Supplement at www.int-res.com/articles/suppl/n033 p039_supp.pdf) and show the estimated oral oil doses based on the minimum $(0.34 \mathrm{~kg})$, mean $(1.42 \mathrm{~kg})$ and maximum $(4.00 \mathrm{~kg})$ turtle BWs. Table 2 presents the summary of these calculations using the mean turtle BW. For all calculations, a correction factor for oil mass of $1.2 \mathrm{ml} \mathrm{oil} \mathrm{g}^{-1}$ (based on an oil specific gravity of 0.833 ) was used to convert the volume of oil to mass of oil so that the dose data are reported in standard units, i.e. mg oil $\mathrm{kg}^{-1}$ BW turtle $\mathrm{d}^{-1}$. Furthermore, it was assumed that the volume estimated in the mouth and esophagus (oral cavity) by Stacy (2012) was a total daily dose. So, to compare with the other vertebrate daily doses (calculated in the next subsection), estimates of daily oil doses for the 2 lowest oiling categories (using the mean turtle BW) using the minimum, mean and maximum oral estimates would range from 29 to 88 and from 146 to $293 \mathrm{mg}$ oil kg $\mathrm{kg}^{-1} \mathrm{BW}$ turtle $\mathrm{d}^{-1}$ for categories 1 and 2, respectively (see Table 2 ).

Exposure data were presented both as a daily instantaneous dose estimate and as a combined $14 \mathrm{~d}$ estimate (see Tables S4 \& S5 in the Supplement). A daily dose was calculated to allow comparison with literature reporting daily oil doses in other species (see 'Results and discussion'). Although many potential exposure scenarios are possible for turtles during the approximately 3 mo DWH spill time period, a $14 \mathrm{~d}$ exposure was chosen to represent one potential and likely exposure regime during the oil release period. A $14 \mathrm{~d}$ exposure regime was also used in a recent DWH oil exposure study in 2 species of freshwater turtles (Mitchelmore et al. 2015b). Therefore, these $14 \mathrm{~d}$ exposure calculations are provided in the Supplement as an example of an exposure scenario greater than the daily dose estimate. However, our toxicological comparisons to other published studies in this report are primarily based on the daily dose estimates in Table 2, given the limited amount of data available for comparison to other species' exposure scenarios. Furthermore, it is unknown exactly how long a single ingested exposure, coating the esophagus, would expose a sea turtle to oil. We provide the $14 \mathrm{~d}$ cumulative oil exposure calculation (Table S4 in the Supplement) to highlight the complexity of multiple-day exposure scenarios, which would include a consideration of accumulation and depura- 
Table 2. Estimation of daily instantaneous doses in oceanic sea turtles in the 4 oiling categories using the minimum, mean and maximum estimates for oral oil volume as detailed in Table 1. Numbers are presented based on average turtle body weight (BW), with values in parentheses showing daily dose ranges based on maximum, mean and minimum turtle weights. Data from Mitchelmore (2012a,b)

\begin{tabular}{|c|c|c|c|}
\hline \multirow{2}{*}{$\begin{array}{l}\text { Extent of } \\
\text { visual exter- } \\
\text { nal oiling } \\
\text { (category) }\end{array}$} & \multicolumn{3}{|c|}{$\begin{array}{l}\text { Daily dose for all } 3 \text { oral volume estimates } \\
\left.\text { (mg oil } \mathrm{kg}^{-1} \mathrm{BW}\right)\end{array}$} \\
\hline & Minimum & Mean & Maximum \\
\hline 1 & $\begin{array}{c}29 \\
(10-123)\end{array}$ & $\begin{array}{c}59 \\
(21-245)\end{array}$ & $(31-$ \\
\hline 2 & $\begin{array}{c}146 \\
(52-613)\end{array}$ & $\begin{array}{r}2 \\
(79\end{array}$ & 2 \\
\hline 3 & $\begin{array}{c}585 \\
(208-2451)\end{array}$ & 11 & 17 \\
\hline $4^{\mathrm{a}}$ & $\begin{array}{c}2341 \\
(833-9804)\end{array}$ & $\begin{array}{c}3512 \\
(1250-14700)\end{array}$ & $\begin{array}{c}4683 \\
(1667-19608)\end{array}$ \\
\hline \multicolumn{4}{|c|}{$\begin{array}{l}{ }^{\text {a }} \text { Data provided for completeness but not included in our } \\
\text { mortality assessments. Further details can be found in } \\
\text { Tables S1 to S3 in the Supplement at www.int-res.com/ } \\
\text { articles/suppl/n033p039_supp.pdf }\end{array}$} \\
\hline
\end{tabular}

tion of oil. For example, Table S4 in the Supplement calculates the $14 \mathrm{~d}$ retained dose based on repeated daily doses, with excretion occurring after $9 \mathrm{~d}$. The 9 d oil passage time in turtles was estimated by Vargo et al. (1986b), who found excretion occurring after $9 \mathrm{~d}$ in juvenile sea turtles that ingested crude oil.

\section{Calculations of daily oil ingestion rates in other vertebrate species}

Based on literature searches in Google Scholar, Scopus and Web of Science, few studies have quantified oil exposure and impacts in turtles and other reptiles; therefore, we also considered oil exposure studies in non-reptilian vertebrate species when assessing potential toxicity to sea turtles. This included various bird species (e.g. Lattin \& Romero 2014, Lattin et al. 2014) and mink (e.g. Mohr et al. 2008, 2010), as discussed in this section. We compared the estimated exposure in sea turtles to the levels and effects reported in 2 oil dose-response studies in mink (Mohr et al. 2008, 2010). To compare these mink studies to DWH-exposed sea turtles, calculations of daily doses for the mink studies were necessary. In the first study, male mink were fed 48, 520 and $908 \mathrm{ppm}$ of Bunker $\mathrm{C}$ fuel oil or mineral oil (control) in their diet for 60 to $62 \mathrm{~d}$ (Mohr et al. 2008). In the second study, mink were fed artificially weathered Bunker $\mathrm{C}$ fuel oil or mineral oil controls. For Bunker $\mathrm{C}$ fuel oil, male mink were fed 0, 420 or $480 \mathrm{ppm}$ and female mink were fed 0 and $420 \mathrm{ppm}$ fuel oil in their diet for 60 to $62 \mathrm{~d}$ (Mohr et al. 2010).

Provided the BWs and ingestion rates of the mink are known or can be estimated, then the dietary concentrations can be converted to a daily dose in units of $\mathrm{mg}$ (test agent) $\mathrm{kg}^{-1} \mathrm{BW} \mathrm{d} \mathrm{d}^{-1}$ (USEPA 1993). For mink, conversions of oil concentrations in the diet to a daily dose were based on a normalized ingestion rate of $0.15 \mathrm{~kg}$ of food $\mathrm{kg}^{-1} \mathrm{BW} \mathrm{d} \mathrm{d}^{-1}$ (based on assumptions of a food consumption rate of $0.15 \mathrm{~kg} \mathrm{~d}^{-1}$ and a BW of $1.0 \mathrm{~kg}$; USEPA 1995). BWs of 8 mo old mink range from 1000 to $1500 \mathrm{~g}$ (Wood et al. 1965). Therefore, at $48 \mathrm{ppm}$, oil in the mink diet would represent a daily dose of $7.2 \mathrm{mg}^{-1} \mathrm{~kg}^{-1}$ (i.e. a mink ingesting $0.15 \mathrm{~kg}$ of a $48 \mathrm{mg}$ oil $\mathrm{kg}^{-1}$ food diet). The highest concentration in the 2 studies was $908 \mathrm{ppm}$, which equals a daily dose of $136 \mathrm{mg} \mathrm{kg}^{-1} \mathrm{~d}^{-1}$. Other doses used in the study included a diet of 420 and $520 \mathrm{ppm}$, equal to 63 and $78 \mathrm{mg} \mathrm{kg}^{-1} \mathrm{~d}^{-1}$, respectively. Therefore, daily doses using a $1 \mathrm{~kg}$ BW mink would be 7.2, 136, 63 and $78 \mathrm{mg}$ oil kg ${ }^{-1} \mathrm{BW} \mathrm{d} \mathrm{d}^{-1}$ for the studies described above.

We also used recent studies in house sparrows exposed to oil in their diet for 2 to $4 \mathrm{wk}$ as an additional daily dose comparison, given that birds are a closer taxonomic comparison than a mammalian species. In studies by Lattin \& Romero (2014) and Lattin et al. (2014), house sparrows (average weight $\sim 25 \mathrm{~g}$ ) were fed a diet of $1 \%$ oil in their food (i.e. a $10000 \mathrm{mg}$ oil $\mathrm{kg}^{-1}$ food dose) for 2 to $4 \mathrm{wk}$. This oil was a weathered GoM Louisiana sweet crude oil, which is more similar to DWH oil than the Bunker C used in the mink studies. Wang \& Newman (2013) showed that the food ingestion rate in a similar species, the eastern song sparrow, which is similar in weight to the house sparrow, was estimated to be between 0.1 and $0.4 \mathrm{~g}$ food $\mathrm{g}^{-1} \mathrm{BW}$ and probably was likely to be between 0.1 and

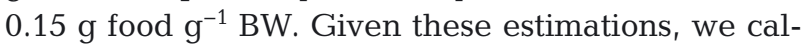
culate that the daily ingested dose for these birds would be around $1000 \mathrm{mg}$ (up to 4000) oil $\mathrm{kg}^{-1} \mathrm{BW} \mathrm{d}^{-1}$.

Furthermore, we compare sea turtle exposure to a recent $14 \mathrm{~d}$ dietary oil exposure in 2 species of freshwater turtles that used daily exposures of 100 and $1000 \mathrm{mg} \mathrm{kg}^{-1} \mathrm{BW} \mathrm{d} \mathrm{d}^{-1}$ for a high- and low-dose exposure, respectively (Mitchelmore et al. 2015b).

\section{RESULTS AND DISCUSSION}

\section{Known toxicological effects of oil exposure in turtles and other vertebrate species}

There are very few studies addressing the toxicological effects of oil and/or chemical dispersants on 
sea turtles (or any turtle species; for a review, see Shigenaka 2003). In the 1980s, a waterborne oil exposure study in loggerhead Caretta caretta and green Chelonia mydas sea turtles examined lethal and sublethal endpoints (Vargo et al. 1986a,b,c, Lutcavage et al. 1995). Juvenile loggerhead and green sea turtles were exposed for $96 \mathrm{~h}$ to a simulated oil spill (i.e. waterborne exposure) using weathered South Louisiana crude oil (Vargo et al. 1986b). The turtles ingested the oil during the exposure period and, thereafter, were evaluated up to 2 mo post-exposure. No excretion of oil by the turtles was observed until $9 \mathrm{~d}$ postexposure, a finding used in the $14 \mathrm{~d}$ oil exposure estimates (Tables S1-S5 in the Supplement). Physiological assessments found some aspects of blood chemistry and composition were impacted by oil exposure. Oil was observed on the nares and eyes and in the upper portion of the esophagus, as well as in the feces. This demonstrated that external oil exposure of sea turtles can result in coating of epidermal surfaces, excretion in the feces after $9 \mathrm{~d}$ and alterations in hematology and blood chemistry (Vargo et al. 1986b, Lutcavage et al. 1995).

Juvenile loggerhead turtles exposed to South Louisiana crude oil floating on top of the water in their tanks for $96 \mathrm{~h}$ at both low exposure $(0.5 \mathrm{~mm}$ thick oil layer) and high exposure (5.0 $\mathrm{mm}$ thick oil layer) exhibited marked and consistent histologic skin changes in both exposure groups, and these effects were more severe in the high-exposure group (Vargo et al. 1986b, Bossart et al. 1995). Skin and exposed mucous membranes began to slough in irregular sheets, beginning after approx. $9 \mathrm{~d}$ and continuing to $21 \mathrm{~d}$, but appeared grossly normal by $40 \mathrm{~d}$ post-exposure. The potential for the skin dysfunction presented a potential portal of entry by pathogenic organisms, and the authors concluded that the turtles would face substantial risks in and after an oil spill (Bossart et al. 1995).

A recent laboratory study orally exposed juveniles of 2 freshwater turtle species (red-eared slider Trachemys scripta elegans and common snapping turtle Chelydra serpentina serpentina) as surrogates for sea turtles to 'Slick A' weathered MC252 oil for $14 \mathrm{~d}$ (DWH Trustees 2015, Mitchelmore et al. 2015b). Two oil doses were used to represent minimally to moderately oiled turtles (i.e. 100 and $1000 \mathrm{mg}$ oil kg-1 BW $\mathrm{d}^{-1}$, respectively) based on the oil ingestion estimates and subsequent daily dose estimates detailed in Mitchelmore $(2012 \mathrm{a}, \mathrm{b})$ and Mitchelmore et al. (2015a). Dose-dependent increases in biliary FACs were observed, but there was no mortality or hemolytic anemia observed after $14 \mathrm{~d}$ of exposure
(DWH Trustees 2015, Mitchelmore et al. 2015b). Some oil-dependent physiological abnormalities were seen, including evidence of dehydration, decreasing digestive function and assimilation of nutrients (DWH Trustees 2015, Mitchelmore et al. 2015b). Some other oil-dependent alterations in common PAH biomarker endpoints including oxidative stress and DNA damage were observed (DWH Trustees 2015, Mitchelmore et al. 2015b). Two red-eared sliders that had received a high dose of DHW Slick A oil for $14 \mathrm{~d}$ showed dysfunction of the hypothalamicpituitary-adrenal (HPA) axis. Although there was a decreasing trend in median corticosterone rise following adrenocorticotropic hormone (ACTH) administration, this was not statistically significant, likely due to the low numbers of animals used for the experiment and the high variation in response observed between individuals coupled with only $14 \mathrm{~d}$ of exposure (DWH Trustees 2015, Mitchelmore et al. 2015b). In the snapping turtles, no statistically significant differences between control and treatment groups in baseline or ACTH-induced corticosterone levels were observed (DWH Trustees 2015, Mitchelmore et al. 2015b). Therefore, the effects of experimental DWH oil exposure on red-eared sliders and common snapping turtles did not consistently indicate HPA dysfunction, although given the limitations to this study and evidence of dysfunction in the redeared sliders, impact to the HPA axis and the animals' responses to future stress events could not be ruled out.

There are very few reports of the effects of oil spills on wild sea turtles. Vargo et al. (1986a) estimated that about $3.2 \%$ of sea turtle strandings reported to the Florida Department of Natural Resources were petroleum-related, and notably $37.7 \%$ were of unknown cause. Among the petroleum-affected sea turtles, the most often reported strandings were from southeastern Florida, and primarily green sea turtles, both adults and juveniles, were affected. Other brief reports describe occurrences of oiled sea turtles and rehabilitation and release efforts of sea turtles during oil spills in the central west coast of Florida and in the Persian Gulf (Anonymous 1991, 1994, Thomas \& Robinson 1991). Computer models of the impact of oil spills on Atlantic loggerhead turtles Caretta caretta indicate that an oil spill accelerates population decline (Leung et al. 2012). Oil exposure has been implicated as the principle cause of strandings of juvenile sea turtles in the Canary Islands, Spain, between 1998 and 2011 (Camacho et al. 2013).

The blowout of the Ixtoc I oil well in Mexico's Bay of Campeche in 1979 resulted in the daily release of 
10000 to 15000 barrels of oil for a period of several months, with the oil drifting northward in the GoM. Green sea turtles and Kemp's ridley sea turtles Lepidochelys kempii were found dead and had petroleum in their upper alimentary systems; there was no evidence that the oil had caused alimentary lesions and no sign of pulmonary aspiration (Hall et al. 1983).

During an oil spill in Puerto Rico in 1994, Mignucci-Giannoni (1999) found that rehabilitated sea turtles (Chelonia mydas and Eretmochelys imbricata), when compared with rehabilitated sea birds, had higher chances of survival after being exposed to an oil spill. Survival estimates were based on the relative health condition of released animals. But as noted by Saba \& Spotila (2003), that does not infer that the sea turtles had no crude oil residuals present in their tissues following rehabilitation (Mignucci-Giannoni 1999). However, survival and post-rehabilitation behavior of 4 species of freshwater turtles exposed to a crude oil spill in February 2000 in a US National Wildlife Refuge indicates that rehabilitation of oil-exposed freshwater turtles can be effective in restoring these animals to normal behavior, based on home range sizes and water temperature preferences (Saba \& Spotila 2003). Modeling from oil exposure to impact in turtles is not entirely novel. For example, population mortality estimates for freshwater diamondback terrapins Malaclemys terrapin were assigned by Michel et al. (2001) following an oil spill in Maryland. However, these estimates were based only on the oiling of the shoreline of the Patuxent River, as no measured levels or estimates of internal exposure were available for the turtles, thereby limiting comparisons to DWH oil-exposed turtles and laboratory oil exposure studies in turtles and other vertebrate species discussed in this subsection (Michel et al. 2001). In the weeks following the Patuxent spill, the extent and degree of shoreline oiling were defined, and mortality estimates associated with different levels of shoreline oiling were as follows: (1) heavily oiled, with $10 \%$ mortality; (2) moderately oiled, with $2 \%$ mortality; and (3) lightly oiled, with $0.5 \%$ mortality within the subpopulations of the turtles that lived in those areas (Michel et al. 2001). This risk assessment approach was similar to ours except that we were able to base our estimates on semi-quantitative observations of external and ingested oil of sea turtles, allowing us to compare findings with laboratory oil exposures in turtles and other vertebrate species.

Mortality estimates for DWH MC252-exposed sea turtles were made based on the variety of clinical and medical parameters assessed (blood chemistry and hematological endpoints) during the rehabilitation of captured sea turtles (Stacy \& Innis 2015, Stacy et al. 2017). Using a series of models that have previously been used in turtles (e.g. see Stacy et al. 2013), an average of $14 \%$ (range 4 to $22 \%$ ) mortality for all of the turtles irrespective of level of oiling would have occurred had they not been rescued (Stacy \& Innis 2015). This was deemed to be a conservative measure, as it does not take into account long-term, sublethal exposures or delayed effects of oil. In a followup study, focusing only on Kemps ridley turtles, a different approach was used which resulted in an estimate of $25 \%$ mortality for this species (Stacy et al. 2017).

Given the paucity of studies of the effects of oil exposure in sea turtles, literature for other marine and freshwater reptiles, mammals and birds was also considered when deriving our mortality estimates. In 2001, an oil spill occurred in the Galapagos Islands, Ecuador, releasing diesel and bunker oil throughout the archipelago of San Cristobal Island in the Galápagos Natural World Heritage Site. Marine iguanas Amblyrhynchus cristatus had been studied on that site since 1981, and a few animals died immediately (Wikelski et al. 2001). Of the 170 individuals examined, $70 \%$ had oil residue on their skin (Wikelski et al. 2001). Plasma levels of corticosterone were highly elevated in animals sampled after the oil spill compared to animals sampled $10 \mathrm{~d}$ prior to the spill. This was true for baseline (within 3 min of capture) and stress-induced levels (stress was a manual restraint of the animals). Corticosterone levels were indistinguishable between animals that had externally visible oil blotches and those without, suggesting that animals in the vicinity of the oil spill were affected even without visible oil exposure. Corticosterone levels in the marine iguana population were linearly related to survival rates (Wikelski et al. 2001).

In contrast, adrenal insufficiency following oil exposure, albeit in longer-term exposures, has been demonstrated in other vertebrate species. For example, within the footprint of the DWH oil spill, bottlenose dolphins Tursiops truncatus exhibited adrenal insufficiency and anemia, low blood-sugar levels and symptoms of liver and lung disease associated with mortality (Schwacke et al. 2014).

Because the HPA response to stress appears to be conserved across vertebrate species, and because there is little information on how oil exposure affects this critical pathway (Moore \& Jessop 2003), we also considered studies on birds and mammals 
exposed orally to oil as potential indicators of toxicity in sea turtles. In a laboratory study of oil-exposed mink, effects on blood chemistry, hematology and cytochrome P450 were observed, in addition to adrenal hypertrophy (Mazet et al. 2000, Beckett et al. 2002, Schwartz et al. 2004, Mohr et al. 2008). Also in mink, dietary exposure to Bunker $\mathrm{C}$ fuel oil for 60 to $62 \mathrm{~d}$ resulted in adrenal hypertrophy in males at all doses tested, including the lowest dose of $48 \mathrm{ppm}$ and up to the highest dose of $908 \mathrm{ppm}$ (i.e. 7.2 and $136 \mathrm{mg}$ oil $\mathrm{kg}^{-1} \mathrm{BW} \mathrm{d} \mathrm{d}^{-1}$, respectively; Mohr et al. 2008). However, those chronic oral exposures to low concentrations of Bunker $\mathrm{C}$ oil did not alter serum or fecal glucocorticoid concentrations. In a second related study, mink were fed artificially weathered fuel oil in their diet for 60 to $62 \mathrm{~d}$, and adrenal hypertrophy was also found at all doses and in both sexes (Mohr et al. 2010).

Recent studies in house sparrows demonstrated that stress levels of corticosterone were reduced following chronic exposure to crude oil for 2 to $4 \mathrm{wk}$ (i.e. oil doses $1000 \mathrm{mg}$ oil $\mathrm{kg}^{-1} \mathrm{BW} \mathrm{d}^{-1}$; Lattin et al. 2014). Ingestion of crude oil also showed a decrease in stress-induced corticosterone levels in mallard ducks (Gorsline \& Holmes 1982). In a similar study, levels of glucocorticoid receptors were decreased in the liver of the oil-exposed birds relative to controls, highlighting that oil may impact the HPA axis at multiple levels and through multiple physiological mechanisms (Lattin \& Romero 2014).

The $14 \mathrm{~d}$ oil exposure laboratory study in 2 species of freshwater turtles using oil doses representative of the low to moderate exposures in DWH-oiled turtles (i.e. $100-1000 \mathrm{mg}$ oil $\mathrm{kg}^{-1} \mathrm{BW} \mathrm{d}^{-1}$ ) also provided some evidence of adrenal dysfunction, including decreased levels of corticosterone following a stress response (discussed earlier in this subsection; see Mitchelmore et al. 2015b). However, conclusions were limited, given the limited number of animals, the large variability in response and the shorter exposure duration period compared with the mink and bird studies.

The results of this literature review confirmed that there is evidence, in reptiles and other vertebrates, that exposure to oil (including chronic low doses and continued impacts post-exposure) adversely affects the adrenal glands and/or their function. It has been suggested that chronic lowdose ingestion of oil can affect not only stressinduced corticosterone levels but also glucocorticoid receptor density, demonstrating that oil can act at multiple levels to disrupt responses in organisms and their ability to survive stressors, including extreme events or predator attack (Lattin et al. 2014). Indeed, an overall general suppression of the stress response has been put forth to at least partially explain why oil-exposed animals show elevated mortality after exposure to subsequent stressors (see Holmes et al. 1979).

\section{Description of the approaches used in defining mortality estimates in oceanic sea turtles exposed to DWH oil}

Our estimates of mortality in less than heavily oiled sea turtles (categories 0-3) are based on the limited information available for oil-related impacts in turtles coupled with evidence derived from other vertebrate species (mink and birds). Based on the estimated daily ingested doses of oil presented in this report, turtles during the DWH spill would be exposed to concentrations of oil that are associated with toxicological effects in turtles and other vertebrate species. For example, using our calculated estimated daily doses of oil (Table 2 and Tables S1-S5 in the Supplement), the exposures estimated for oceanic sea turtles during the DWH oil spill are equal to or substantially higher than a known dose in mink of $7.2 \mathrm{mg}$ $\mathrm{kg}^{-1} \mathrm{~d}^{-1}$, that specifically impacts the HPA axis (Mohr et al. 2008, 2010) for all exposure scenarios. However, it should be noted that the mink experiments were conducted with Bunker C fuel oil and not the DWH MC252 oil. House sparrows exposed to oil for 2 to $6 \mathrm{wk}$ also showed negative impacts to the HPA axis (i.e. reduced stress corticosterone levels and reduced or unchanged [not up-regulated as expected] glucocorticoid receptor levels) using an oil similar to the DWH oil at daily dose levels equivalent (i.e. $1000 \mathrm{mg}$ oil $\mathrm{kg}^{-1} \mathrm{~d}^{-1}$ ) to the moderately exposed sea turtles (see Table 2).

Although it is difficult to compare across different species (species sensitivity issues), oils, doses and exposure periods, based on our daily estimates, it appears that even minimally oiled turtles (category 1) would be at risk for adrenal insufficiency, which would have consequences for long-term survival and fitness of the sea turtle population. This finding is substantiated by the findings of the literature review, including the marine iguana study that indicates that reptiles exposed to oil spills will respond through the HPA axis and that elevated corticosterone responses can be indicators and correlates of reduced survival (Holmes et al. 1979, Wikelski et al. 2001). Hypo- or hyper-adrenal response has been identified as an effect of concern across taxa, including marine igua- 
nas, birds and mammals (Gorsline \& Holmes 1982, Wikelski et al. 2001, Mohr et al. 2008, 2010, Lattin \& Romero 2014, Lattin et al. 2014, Schwacke et al. 2014).

From the evidence in the literature and our modeling, we concluded that sea turtles exposed to the DWH oil spill would likely experience adrenal dysfunction leading to mortality. Adrenal insufficiency can impact turtles in several ways that can reduce population viability through increased mortality and reduced reproduction. For turtles in oiling categories 2 and 3, the estimated daily ingested dose of oil greatly exceeds the dose that would be expected to cause adrenal insufficiency. Turtles in category 4 would also be in this group, but turtles in this group were already considered to have a mortality of $100 \%$ and so are not considered further here in our mortality estimates. For turtles in category 3, where $93 \%$ were observed to have oil in their mouths, a daily dose of oil of 208 to $7353 \mathrm{mg} \mathrm{kg}^{-1} \mathrm{~d}^{-1}$ was estimated, which is orders of magnitude greater than the known dose which specifically impacts the HPA axis in mink of $7.2 \mathrm{mg} \mathrm{kg}^{-1} \mathrm{~d}^{-1}$. Therefore, we initially estimated that all turtles that ingested this amount of oil would have died. However, given the potential for a shorter acute exposure period in sea turtles after the DWH oil spill compared with the mink studies, we concluded that there would have been a minimum of $90 \%$ mortality in category 3 oiled turtles (range of 90-100\%; Table 3). Given that this mortality is only applicable for turtles that have ingested oil (i.e. $93 \%$ ), we estimated an overall mortality for category 3 turtles of $85 \%$ (90\% of $93 \%$; mortality estimates are rounded to the nearest $5 \%$; Table 3).

Using similar reasoning for category 2 turtles, where $76 \%$ had oil in their mouths at high daily dose levels (52-1225 $\mathrm{mg} \mathrm{kg}^{-1} \mathrm{BW} \mathrm{d}^{-1}$ ), and given the same caveat about exposure time, we determined a range of 65 to $80 \%$ mortality in category 2 oiled turtles. Using the lowest estimate of $65 \%$ mortality for only the $76 \%$ of turtles that had ingested oil, $50 \%$ mortality (i.e. $65 \%$ of $76 \%$; Table 3 ) was estimated for category 2. For turtles in category 1 , with visible oil in their oral cavity in $49 \%$ of cases, where the minimum estimated $14 \mathrm{~d}$ dose $\left(10 \mathrm{mg} \mathrm{kg}^{-1} \mathrm{~d}^{-1}\right.$; range $10-36 \mathrm{mg}$ $\mathrm{kg}^{-1} \mathrm{~d}^{-1}$ ) was similar to the lowest exposure in mink that induced adrenal insufficiency, and again given the possibility that exposure duration may be lower in turtles compared to the $62 \mathrm{~d}$ mink study, a $50 \%$

Table 3. Summary of mortality estimates calculated for DWH-exposed oceanic turtles. STTWG: sea turtle technical working group; HPA: hypothalamic-pituitary-adrenal

\begin{tabular}{|c|c|c|}
\hline $\begin{array}{l}\text { Oiling } \\
\text { cate- } \\
\text { gory }\end{array}$ & $\begin{array}{l}\text { Min. mor- } \\
\text { tality esti- } \\
\text { mate }(\%)\end{array}$ & Description and rationale used in ascribing mortality value \\
\hline 4 & $100^{\mathrm{a}}$ & $\begin{array}{l}\text { The STTWG determined that } 100 \% \text { of heavily oiled turtles would have died but for their capture } \\
\text { and rehabilitation, primarily due to the physical effects of being mired in heavy oil in high temper- } \\
\text { atures. Therefore, this report does not assess mortality in this category, although it does model } \\
\text { potential exposure in this group. }\end{array}$ \\
\hline 3 & 85 & $\begin{array}{l}\text { This mortality estimate is calculated using our estimated daily oil doses for } 14 \mathrm{~d} \text { that far exceed } \\
\text { the dose of oil shown to cause adrenal insufficiency in other vertebrate species. Based on the } \\
\text { impact to the HPA axis alone, } 90 \text { to } 100 \% \text { mortality is expected in the } 93 \% \text { of turtles that had } \\
\text { ingested oil. However, given the potential for reduced exposure time to reduce impacts, a mini- } \\
\text { mum estimate of } 85 \% \text { mortality }(90 \% \text { of } 93 \% \text { ) was concluded. }\end{array}$ \\
\hline 2 & 50 & $\begin{array}{l}\text { The rationale for the estimates for this category is as described for category 3, except mortality } \\
\text { via HPA axis impact was reduced to a range from } 65 \text { to } 80 \% \text {; therefore, the minimum } 65 \% \text { esti- } \\
\text { mate was used in these analyses. Using the lowest estimate of } 65 \% \text { mortality for only the } 76 \% \text { of } \\
\text { turtles that had ingested oil, } 50 \% \text { mortality (i.e. } 65 \% \text { of } 76 \% \text { ) was estimated. }\end{array}$ \\
\hline 1 & 25 & $\begin{array}{l}\text { The rationale for the estimates for this category is the same as that described for category } 3 \text {, } \\
\text { except mortality via HPA axis impact ranges from } 50 \text { to } 65 \% \text {; using the minimum } 50 \% \text { mortality } \\
\text { estimate applied to the } 50 \% \text { of turtles in this category that had oil in their oral cavity, an overall } \\
\text { minimum mortality estimate of } 25 \% \text { (i.e. } 50 \% \text { of } 50 \% \text { ) was assigned to this group. }\end{array}$ \\
\hline 0 & 0 & No oil exposure externally or internally visible. ${ }^{\mathrm{b}}$ \\
\hline
\end{tabular}




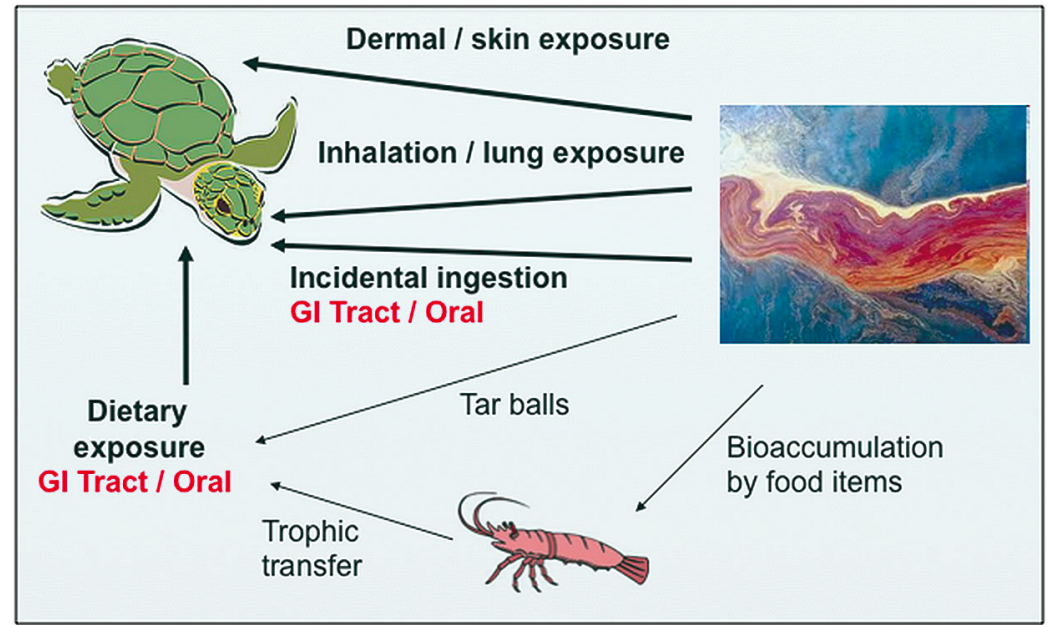

Fig. 1. Potential routes of oil exposure to oceanic sea turtles. Redrawn from Mitchelmore (2012a). GI: gastrointestinal after they were initially assessed) to low-level chronic oil exposures that may not have been visible from external and internal observation of live turtles.

We believe these to be minimum estimates because other factors that were not quantified during the DWH spill could contribute to mortality, including multiple exposure routes (see Fig. 1). Turtles can ingest oil by mouth and be exposed through other orifices (e.g. nares) when oil is floating and mixed in the water. Turtles may also consume oil-contaminated prey or tar balls mistaken as prey, and inhalation or aspiration of oil or oilderived compounds is also a likely route of exposure (Fig. 1). Persistent, delayed or sublethal effects from physical impairment (Fig. 2) other than adrenal dysfunction were not considered, e.g. heat stress, reduced fitness and implications for effects on behavior affecting foraging and predator avoidance. Impacts resulting from exposure to chemical dispersants or chemically dispersed oil represent an additional unknown toxicity concern.

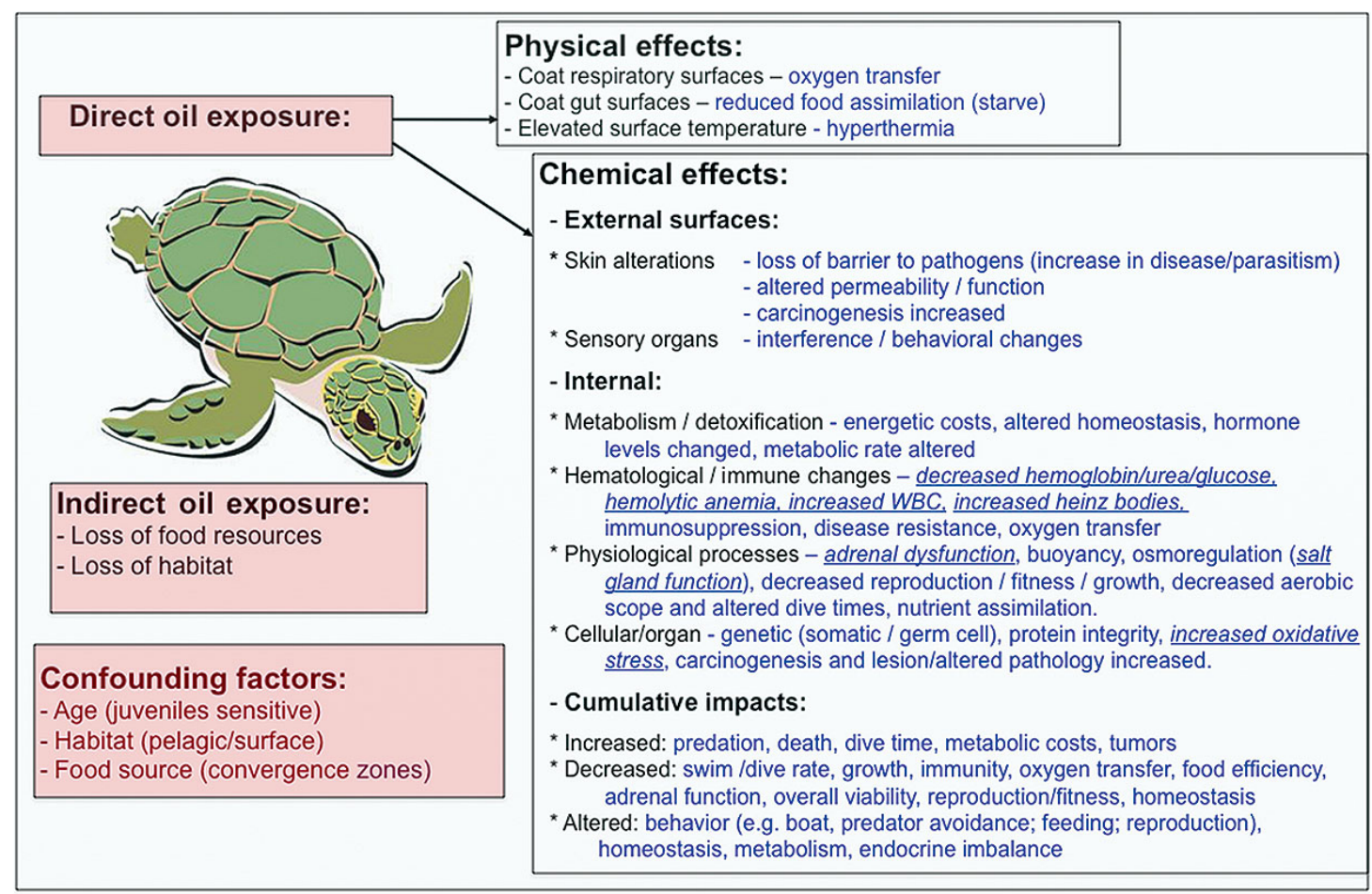

Fig. 2. Potential direct and indirect effects of oil (including toxicological endpoints) on turtles. Redrawn from Mitchelmore (2012a) 


\section{Calculation of mortality of sea turtles in categories 0 to 3}

To calculate the number of dead sea turtles in less than heavily oiled turtles (i.e. categories 0 to 3 ), our percentage estimations were applied to the known numbers of turtles documented by direct capture operations during the DWH spill (Stacy 2012, DWH Trustees 2015, Wallace et al. 2017 and Table 4) that were assigned to each of the oiling categories. This was calculated as $25 \%$ of 266 turtles in category 1 (i.e. 66.5$), 50 \%$ of 87 turtles in category 2 (i.e. 43.5) and $85 \%$ of 47 turtles in category 3 (i.e. 40 ) $=150$ dead turtles, which is approximately $30 \%$ of the 510 turtles examined (Table 4). Therefore, we project an overall mortality of $30 \%$ for all oceanic turtles within the footprint of the DWH oil spill in addition to those already presumed to have died from heavy oiling (i.e. category 4). This mortality estimate has been used by other researchers to estimate the total number of turtles that may have died in the DWH footprint (e.g. DWH Trustees 2015, McDonald et al. 2017 [this Theme Section]).

\section{CONCLUSIONS AND SUMMARY}

Using field observations of oil ingestion by sea turtles following the DWH oil spill, our oil exposure estimates, a review of existing scientific literature and results from a laboratory study on a surrogate turtle species, we concluded that there is strong potential for substantial biological perturbation, reduced fitness and subsequent mortality in any sea turtle exposed to oil from the DWH oil spill. The mortality estimates provided here are minimum estimates, especially considering the potential for additional effects from other exposure routes and

Table 4. Total number of sea turtles (all species) documented by direct capture during the DWH oil spill in categories 0 to 3 and the percentage mortality assigned by the percentage mortality in each category, together with a final estimate for the number of dead turtles

\begin{tabular}{|lccccc|}
\hline \multicolumn{7}{c}{ Cat. 0 } & Cat. 1 & Cat. 2 & Cat. 3 Total \\
\hline No. of turtles & & & & & \\
Mortality estimate $(\%)^{\mathrm{b}}$ & 110 & 266 & 87 & 47 & 510 \\
No. of dead turtles & 0 & 66.5 & 43.5 & 40 & 150 \\
a As described in DWH & Trustees $(2015)$, Wallace et al. \\
(2017) \\
bummary for each category, calculated using mortality \\
estimates applied only to turtles with oil in their oral \\
cavity (see Tables 1 \& 3)
\end{tabular}

the currently unknown potential for delayed effects that may manifest at individual and population levels for years to come.

Acknowledgements. We acknowledge assistance from Dr. Mike Hooper in the calculation of the daily and $14 \mathrm{~d}$ oil dose estimates and Dr. Bryan Wallace and Dr. Karen Dean for literature and other additional assistance. This paper is contribution number 5225 of the University of Maryland Center for Environmental Science, Chesapeake Biological Laboratory.

\section{LITERATURE CITED}

Anonymous (1991) Oil spill in the Persian Gulf threatens sea turtles. Mar Turtle Newsl 53:32

Anonymous (1994) Tampa Bay oil spill threatens turtles. Mar Turtle Newsl 64:29

*Beckett KJ, Aulerich RJ, Duffy LK, Patterson JS, Bursian SJ (2002) Effects of dietary exposure to environmentally relevant concentrations of weathered Prudhoe Bay crude oil in ranch-raised mink (Mustela vison). Bull Environ Contam Toxicol 69:593-600

Bossart GD, Lutcavage M, Mealey B, Lutz P (1995) The dermatopathologic effects of oil on loggerhead sea turtles (Caretta caretta). In: Frink L, Ball-Weir K, Smith C (eds) Wildlife and oil spills: response, research and contingency planning. Sheridan Press, Hanover, PA, p 180-181

* Camacho M, Calabuig P, Luzardo OP, Boada LD, Zumbado M, Orós J (2013) Crude oil as a stranding cause among loggerhead sea turtles (Caretta caretta) in the Canary Islands, Spain (1998-2011). J Wildl Dis 49:637-640

DWH Trustees (Deepwater Horizon Trustees) (2015) Deepwater Horizon oil spill: draft programmatic damage assessment and restoration plan and draft programmatic environmental impact statement. National Marine Fisheries Service, NOAA, Silver Spring, MD. www.gulfspillrestoration.noaa.gov/restoration-planning/gulf-plan/

Goodman Hall A, Belskis LC (2012) Guide to the aerial identification of sea turtles in the US Atlantic and Gulf of Mexico. NOAA Tech Memo NMFS-SEFSC-633

* Gorsline J, Holmes WN (1982) Suppression of adrenocortical activity in mallard ducks exposed to petroleum-contaminated food. Arch Environ Contam Toxicol 11:497-502

Hall RJ, Belisle AA, Sileo L (1983) Residues of petroleum hydrocarbons in tissues of sea turtles exposed to Ixtoc oil spill. J Wildl Dis 19:106-109

Holmes WN, Gorsline J, Cronshaw J (1979) Effects of mild cold stress on the survival of seawater-adapted mallard ducks (Anas platyrhynchos) maintained on food contaminated with petroleum. Environ Res 20:425-444

Lattin CR, Romero LM (2014) Chronic exposure to a low dose of ingested petroleum disrupts corticosterone receptor signaling in a tissue-specific manner in the house sparrow (Passer domesticus). Conserv Physiol 2:cou058

Kattin CR, Ngai HM, Romero LM (2014) Evaluating the stress response as a bioindicator of sub-lethal effects of crude oil exposure in wild house sparrows (Passer domesticus). PLOS ONE 9:e102106

* Leung MR, Marchand M, Stykel S, Huynh M, Flores JD (2012) Effect of localized oil spills on Atlantic loggerhead population dynamics. Open J Ecol 2:109-114 
Lutcavage ME, Lutz PL, Bossart GD, Hudson DM (1995) Physiologic and clinicopathologic effects of crude oil on loggerhead sea turtles. Arch Environ Contam Toxicol 28: 417-422

Mazet JK, Gardner IA, Jessup DA, Lowenstine LJ, Boyce WM (2000) Evaluation of changes in hematologic and clinical biochemical values after exposure to petroleum products in mink (Mustela vison) as a model for assessment of sea otters (Enhydra lutris). Am J Vet Res 61: 1197-1203

McDonald TL, Schroeder BA, Stacy BA, Wallace BP and others (2017) Density and exposure of surface-pelagic juvenile sea turtles to Deepwater Horizon oil. Endang Species Res 33:69-82

McNutt MK, Camilli R, Crone TJ, Guthrie GD and others (2012) Review of flow rate estimates of the Deepwater Horizon oil spill. Proc Natl Acad Sci USA 109:2026020267

Michel J, Greer R, Hoffman M, McGowan P, Wood R (2001) Acute mortality of diamondback terrapins from the Chalk Point oil spill. Damage Assessment, Remediation, and Restoration Program, NOAA, Seattle, WA

Mignucci-Giannoni AA (1999) Assessment and rehabilitation of wildlife affected by an oil spill in Puerto Rico. Environ Pollut 104:323-333

Mitchelmore CL (2012a) Estimation of potential impacts (mortality) to sea turtles oiled during the Deepwater Horizon oil spill event (2010). Contract report to IEC and NRDA turtle subgroup. https://pub-dwhdatadiver.orr. noaa.gov/dwh-ar-documents/894/DWH-AR0105661.pdf

Mitchelmore CL (2012b) Addendum to estimation of potential impacts (mortality) to sea turtles oiled during the Deepwater Horizon oil spill event (2010). Contract report to IEC and NRDA turtle subgroup. https://pub-dwhdatadiver.orr.noaa.gov/dwh-ar-documents/894/DWH-AR 0105674.pdf

Mitchelmore CL, Bishop C, Collier TK (2015a) Estimated mortality of oceanic sea turtles oiled during the BP Deepwater Horizon oil spill. Expert toxicology panel technical report. https://pub-dwhdatadiver.orr.noaa.gov/dwh-ardocuments/894/DWH-AR0301728.pdf

Mitchelmore CL, Stacy B, Rowe CL, Clayton L and others (2015b) Examination of potential oil toxicity to freshwater turtles as surrogates for sea turtles. DWH sea turtles NRDA technical working group report. Prepared for NOAA Assessment and Restoration Division. https://pubdwhdatadiver.orr.noaa.gov/dwh-ar-documents/894/DWHAR0155176.pdf

Mohr FC, Lasley B, Bursian S (2008) Chronic oral exposure to bunker $\mathrm{C}$ fuel oil causes adrenal insufficiency in ranch mink (Mustela vison). Arch Environ Contam Toxicol 54: 337-347

Mohr FC, Lasley B, Bursian S (2010) Fuel oil-induced adrenal hypertrophy in ranch mink (Mustela vison): effects of sex, fuel oil weathering, and response to adrenocorticotrophic hormone. J Wildl Dis 46:103-110

Moore IT, Jessop TS (2003) Stress, reproduction, and adrenocortical modulation in amphibians and reptiles. Horm Behav 43:39-47

Saba VS, Spotila JR (2003) Survival and behavior of freshwater turtles after rehabilitation from an oil spill. Environ Pollut 126:213-223

Schwacke LH, Smith CR, Townsend FI, Wells RS and others (2014) Health of common bottlenose dolphins (Tursiops truncatus) in Barataria Bay, Louisiana, following the
Deepwater Horizon oil spill. Environ Sci Technol 48: 93-103

Schwartz JA, Aldridge BM, Stott JL, Mohr FC (2004) Chronic fuel oil toxicity in American mink (Mustela vison). Systemic and hematological effects of ingestion of a low concentration of bunker $\mathrm{C}$ fuel oil. Toxicol Appl Pharmacol 200:146-158

Shigenaka G (ed) (2003) Oil and sea turtles: biology, planning, and response. Office of Response and Restoration, National Ocean Service, NOAA, Seattle, WA

Stacy BA (2012) Summary of findings for sea turtles documented by directed captures, stranding response, and incidental captures under response operations during the BP DWH MC252 oil spill. DWH sea turtles technical working group report. https://pub-dwhdatadiver.orr.noaa.gov/dwh-ar-documents/894/DWH-AR 0149670.pdf

Stacy NI, Innis C (2015) Analysis and interpretation of hematology and blood chemistry values in live sea turtles documented by response operations during the 2010 BP Deepwater Horizon oil spill response. DWH sea turtles NRDA technical working group report. https://pubdwhdatadiver.orr.noaa.gov/dwh-ar-documents/894/DWHAR0149939.pdf

Stacy NI, Innis C, Hernandez JA (2013) Development and evaluation of three mortality prediction indices for coldstunned Kemp's ridley sea turtles (Lepidochelys kempii). Conserv Physiol 1:cot003

Stacy NI, Field CL, Staggs L, MacLean RA and others (2017) Clinicopathological findings in sea turtles assessed during the Deepwater Horizon oil spill response. Endang Species Res 33:25-37

Thomas T, Robinson I (1991) Turtles rehabilitated after Persian Gulf oil spills. Mar Turtle Newsl 55:26-27

USEPA (United States Environmental Protection Agency) (1993) Wildlife exposure factors handbook. EPA/600/R93/187, Washington, DC

USEPA (United States Environmental Protection Agency) (1995) Great Lakes water quality initiative criteria documents for the protection of wildlife: DDT, mercury, 2,3,7,8-TCDD, PCBs. EPA-820-B-95-0083, Washington, DC

Vargo S, Lutz P, Odell D, Van Vleet E, Bossart G (1986a) Effects of oil on marine turtles, Vol 1: executive summary. Florida Institute of Oceanography. Final Report MMS NO 14-12-0001-30063

Vargo S, Lutz P, Odell D, Van Vleet E, Bossart G (1986b). Effects of oil on marine turtles, Vol 2: technical report. Florida Institute of Oceanography. Final Report MMS NO 14-12-0001-30063

Vargo S, Lutz P, Odell D, Van Vleet E, Bossart G (1986c). Effects of oil on marine turtles, Vol 3: appendices. Florida Institute of Oceanography. Final Report MMS NO 14-120001-30063

太ैWallace BP, Stacy BA, Rissing M, Cacela D and others (2017) Estimating sea turtle exposures to Deepwater Horizon oil. Endang Species Res 33:51-67

* Wang J, Newman MC (2013) Projected Hg dietary exposure of 3 bird species nesting on a contaminated floodplain (South River, Virginia, USA). Integr Environ Assess Manag 9:285-293

Wikelski M, Romero LM, Snell HL (2001) Marine iguanas oiled in the Galapagos. Science 292:437-438

W Wood AJ, Cowan IM, Daniel MJ (1965) Organ weight-body weight relations in the family mustelidae: the mink 
(Mustela vison). Can J Zool 43:55-68

Ylitalo G, Collier T, Stacy B (2015) Sea turtle exposure to MC252 oil and dispersants in the northern Gulf of Mexico during and following the Deepwater Horizon spill: results of chemical analyses of tissues, bile and gastroenteric contents from necropsied sea turtles. DWH sea turtles NRDA technical working group report. https://

Editorial responsibility: Michael Ziccardi (Guest Editor),

Davis, California, USA pub-dwhdatadiver.orr.noaa.gov/dwh-ar-documents/896/ DWH-AR0177314.pdf

Ylitalo GM, Collier TK, Anulacion BF, Juaire K and others (2017) Determining oil and dispersant exposure in sea turtles from the northern Gulf of Mexico resulting from the Deepwater Horizon oil spill. Endang Species Res 33: $9-24$

Submitted: March 29, 2016; Accepted: August 8, 2016 Proofs received from author(s): September 22, 2016 